\title{
The Practical Perceptions of Vietnamese Lecturers and Students Towards Written Peer Feedback
}

\author{
Pham Vu Phi Ho ${ }^{1}$, Nguyen Minh Thien ${ }^{2}$, Ho Huyen $\mathrm{Ly}^{3} \&$ Nguyen Ngoc Hoang Vy ${ }^{1}$ \\ ${ }^{1}$ Van Lang University, Vietnam \\ ${ }^{2}$ Dong Nai Technology University, Vietnam \\ ${ }^{3}$ Savannah Technical College, USA \\ Correspondence: Pham Vu Phi Ho, Van Lang University, Vietnam. E-mail: phamvuphiho@gmail.com
}

Received: September 20, 2020

Accepted: October 20, $2020 \quad$ Online Published: October 28, 2020

doi:10.5539/ijel.v10n6p347

URL: https://doi.org/10.5539/ijel.v10n6p347

\begin{abstract}
Research studies have shown the benefits of employing written peer feedback (WPF) in classrooms around the world. However, implementing it appropriately in the classrooms is not consistent in the context of universities in Vietnam. The current paper explored the extent to which WPF had applied in the academic writing English classrooms at a university in Vietnam and the practical perceptions of the lecturers and students on this issue. 338 out of 996 students and three lecturers were participated to respond to the survey questionnaire and interviews for analysis. The study revealed that though WPF was carried out in most academic writing classrooms, the implementation was not sufficient to take full benefits of this kind of activity. The students were not sufficiently trained to use this activity appropriately. However, the students obtained highly positive perceptions towards the use of WPF in the classrooms because it provided students opportunities to learn from each other and improve their writing outcomes.
\end{abstract}

Keywords: written peer feedback, academic writing, teacher feedback, writing comments, writing quality

\section{Introduction}

It is undeniable that writing plays an important role in teaching and learning a language. 'The pen is mightier than the sword' is a famous quote that could perfectly capture the power of writing. 'It is one of humankind's most powerful tools' (Macarthur, Graham, \& Fitzgerald, 2006). It is an important means of self-expression. It helps us communicate with others, allowing us to maintain a personal link with family, friends, colleagues who are removed by distance or time. Besides, writing helps convey knowledge and ideas via facilitating the work of gathering, preserving, and transmitting information with great detail and accuracy (Macarthur, Graham, \& Fitzgerald, 2006). In 'Theory and Practice of Writing', Grabe and Kaplan (1996) state that a true representation of the correct forms of language is the written language that should be valued and practiced. However, the acquisition of academic writing is a long-term matter, which requires teachers to search for proper methods to support students in developing their writing competence.

In the teaching writing process, giving responses-feedback on students' writing pieces has an important consequence for students as well as teachers, which can greatly influence students' attitudes towards writing and their motivation for future learning. Students can be positively motivated to explore many areas of knowledge and personal creativity through constructive and supportive responses to their writing (Grabe \& Kaplan, 1996). Their impact on students is apparent to any person involved in academic teaching and learning context.

There are two main types of feedback that learners can get on their writing. They are the teacher's feedback and peer feedback. Teacher's feedback on learners' writing is an orthodox method which leaves teacher much paperwork to evaluate and often happens at the last stage. In the case of the latter, it might make learners neglect revisions because they have already got the grades from their teacher. Since the 1980s, as a result of many studies conducted to find effective responses to complement and support teacher ones, peer feedback has appeared. Its purpose is to generate and receive different points of view and thus raise learners' awareness of the composting process. Besides providing learners with more options to consider in revising their writing papers, it helps them be more specific and helpful in their responses to a peer's essay if they receive adequate training, guidance, and practice (Ekşi, 2012). It is a powerful tool for ESL/EFL learners to improve their writing (Min, 
2006).

Generally, EFL teaching in Vietnam has traditionally focused on form and has been considered a difficult skill to handle. English writing, in particular, has been quite product-oriented. First, based on the language knowledge following a set of conventions derived from a sample or model of a certain writing genre, the written product is evaluated (Pham \& Usaha, 2016; Tran, 2007; Pham \& Pham, 2015). Second, most EFL teachers in Vietnam hold the belief that writing is a complicated skill to teach, which, more or less affects students' learning outcomes (Nguyen, 2009). Learners, in turn, often feel anxious and unconfident when dealing with it (Le, 2008).

Teaching and learning writing is important and demanding which requires teachers and learners great effort. To help learners and teachers in this process, peer feedback is proposed. The use of student peer feedback dispels the traditional notion that feedback is solely the teacher's role and responsibility (Fallows \& Chandramohan, 2001). It allows learners to negotiate the meaning and comment on their peers' work, its implementation can create and facilitate communication in classroom society. The practice of which gives the learner a role of a communicator - a member of class society, which encourages them to be active in managing their learning and gives them opportunities to have meaningful inputs from others (Pearce, Mulder, \& Biak, 2009). In this cooperative learning environment, the roles of learners are shifted from passive receivers of information into active participants (McGourty, Mominick, \& Reilly, 1998).

With changes in writing pedagogy from a product-oriented approach to a process-oriented approach, summative feedback, focusing on writing as a product, has been supplemented or replaced by formative feedback, pointing forward to the students' future writing and the development of their writing process. To efficiently perform the process writing, teacher-written comments are usually combined with peer feedback. The use of peer feedback is highly valued by many researchers. When becoming a critical reader of other's writing, learners can be critical readers and reviser for their writing (Rollinson, 2005). Also, Caulk (1994) finds that teacher's feedback was rather general, whereas students' responses are more specific. It, in sum, gives more control and autonomy to students for it involves students actively in the feedback process instead of passive reliance on teachers' feedback to adjust their writing.

Nevertheless, peer feedback was originally employed to develop L1 learners' writing skills in the 1970s (Hyland \& Hyland, 2006), its effectiveness is still a controversial issue, especially in EFL academic context. In Japan, for example, although group work is employed in teaching oral classes, teachers have not paid enough attention to peer feedback activities (Hirose, 2007). Examining the use of peer feedback, the researcher finds some main arguments about (1) students' attitudes towards it, (2) quality of peers' comments, and (3) the impacts of peer feedback on revisions and writing performance.

The first debate about the application of peer feedback relates to students' perceptions and attitudes. Mangelsdorf (1992) finds that students have positive perceptions of and pay good attention to peer-reviewing. They spend a large amount of time reading and making comments. On the contrary, Leki (1990) reports that some students resent having to review and comment on other students' work. They hold the belief that it is their teacher's responsibility. Also, Cheng and Warren (1997) adds that they feel doubtful about the competence of their peers' comments. They believe the feedback they receive is invalid, thus they refuse to take negative feedback (Topping, 1998).

Second, the quality of comments in applying peer feedback is still questionable. Participating in reviewing peers' writing and receiving feedback from many peers, students have chances to expose to a greater diversity of perspectives than just those of their teacher. They could receive in-depth and detailed feedback (Pearce, Mulder, $\&$ Baik, 2009). On the other hand, reviewers in peer feedback are usually unprepared for such a challenging task. They lack confidence in their ability to evaluate their peers' work. Thus, they may provide vague or unhelpful feedback (Cheng \& Warren, 1997; Min, 2008).

In Vietnam, English writing is quite product-oriented (Pham \& Usaha, 2011; Pham, 2013) and conducted as individual activities with a solo audience - teacher in accompany with rather quiet and passive students (Tran, 2001). In writing classes, little cooperative learning among students is found. Students get feedback on their written product mainly from their teacher, rarely from their peers, Tran (2001) adds. The implementation of peer feedback is, therefore, questionable. In an attempt to put peer feedback into practice, Pham (2010), in his research on blog-based peer response for L2 writing revisions, finds that students expressed their positive attitudes towards peer response, and the total revisions made by peer response gradually increased from the first drafts to the third drafts. Nguyen (2010) also claims that most of the students in her research (78\%) found peer feedback helpful in improving their writing. Nguyen (2012), in her case study at Ho Chi Minh City University of Education, points out that her students took positive attitudes to peer feedback, made constructive comments on 
their peers' drafts, and used their peers' comments to revise their writing. On the contrary, Nguyen (2008) argues that students faced a lot of difficulties in generating feedback on their peers' writing. Moreover, when giving feedback, they paid very little attention to the organization of their peers' writing pieces. Bui (2000) adds that students frequently gave general comments on their peers' drafts and found it difficult to make suggestions to improve the content of their peers' writing.

Studies carried out in this field have yielded both positive and negative results, especially in EFL teaching and learning context. Although many scholars assert the validity of such an interactive approach in writing classroom (Fujida, 2007), and that it is possible to say that peer feedback has useful effects on students' writing quality (Pham, 2019). Pham, Huyen, \& Nguyen (2020) found that peer feedback had great impacts on the students' writing quality and that most of the revisions were triggered by peer feedback. In a research on teaching and learning English writing at Foreign Language Faculty at a University in Ho Chi Minh City, Pham (2013) concludes that students were given few opportunities to work in writing groups and practice peer feedback, and most of the comments on writing were from the teachers in charge for they held the belief that students were not competent enough to generate comments on their peers' product. His descriptive research, however, was limited on Writing-1 and Writing-3, which calls for a broader study on all of the Academic Writing Courses designed for English-majored students: Writing-1, Writing-2, and Writing-3. The gap of previous research and literature led the researcher to conduct the present study to examine to what extent it is applied in the Faculty of Foreign Languages at a University in Ho Chi Minh City with participants from all courses. The present study is to explore how English-majored students in the Faculty of Foreign Languages at a University in Ho Chi Minh City perceive peer feedback based on their regular experiences in writing courses, and examine whether it is feasible and beneficial to apply written peer feedback and if it has effects on their English writing quality.

\subsection{Research Questions}

To fulfill the purpose of the study, the survey was seeking to answer the following research questions:

1) To what extent is written peer feedback applied in English Academic Writing classes in the Faculty of Foreign Languages at a university in Ho Chi Minh City?

2) What are English-majored students' attitudes towards written peer feedback applied in Academic Writing classes?

\section{Methods}

\subsection{Pedagogical Setting}

In the second semester of the school years, there were 16 English writing classes in the Faculty of Foreign Language including Writing-1 (WRT1) and Writing-3 (WRT3). There was a total of 726 students and 6 teachers in charge of those classes. In the third semester of the academic years, there were 6 Writing-2 (WRT2) classes with 135 students. During the first two years, the students were required to take three compulsory English writing courses such as Writing-1: The Paragraphs; Writing-2: The Short Essays; Writing-3: The Essays.

The coursebook used for Writing-1 is Effective Academic Writing by Savage and Shafiel (2007). "Effective Academic Writing 1" is designed according to the unit and emphasizing that writing is a process that consists of several steps: (1) Stimulating Ideas, (2) Brainstorming and Outlining, (3) Developing ideas, (4) Editing your writing, and (5) Putting it all together. "Effective Academic Writing 2" by Savage and Mayer (2005) is used for Writing-2. This book is also designed according to the unit to help students develop short essays. Students are trained on how to organize essays. There are four genres that students learn in this course: (1) Descriptive essays, (2) Narrative essays, (3) Opinion essays, and (4) Comparison and Contrast essays. In the last course of English Writing, students study the course book "Effective Academic Writing-3" by Davis and Liss (2006). They have trained more advanced essays: (1) The Five-paragraph essays, (2) Process Analysis essays, (3) Cause and Effect essays, (4) Argumentative essays, (5) Classification essays, and (6) Reaction essays. Similarly, the book is divided into separate units.

\subsection{Participants}

In terms of selecting a sample for the survey to explore the implementation of written peer feedback, the participants were drawn out from the population of 996 students who were in the first and second year of study and 6 teachers in charge of English Academic Writing of the Faculty of Foreign Language. The population included students who were studying Writing-1 (WRT1), 360 students, and Writing-3 (WRT3), 366 students, in the second semester of 2011-2012 school year, and Writing-2 (WRT2), 270 students, in the third semester of this academic year. There were 8 classes of Writing-1, 6 classes of Writing-2, and 8 classes of Writing- 3 in total. 
Regarding the questionnaire survey, cluster sampling was conducted to select the participants of the study. The students of 4 WRT1 classes, 3 WRT2 classes, and 4 WRT3 classes were randomly chosen from the population for questionnaire delivery. According to the student lists, 495 students were expected to be participants of the present study. However, after delivering the questionnaire, 338 out of 360 were the number of responses collected. The reason for this was that some students skipped the class and some did not complete and return their responses. Concerning the interview survey, in the second and the third semester, 6 teachers were teaching WRT1 and WRT3. Three of them were randomly interviewed to get in-depth information on written peer feedback implementation. Two of them were full-time teachers and the other was a part-time teacher.

Table 1. Samples of the study

\begin{tabular}{lllll}
\hline & WRT 1 & WRT 2 & WRT 3 & Total \\
\hline Classes & 8 & 6 & 8 & 22 \\
Students & 360 & 270 & 366 & 996 \\
Administered questionnaires & 120 & 120 & 120 & 360 \\
Collected Questionnaires & & & & 336 \\
Teachers for interviews & & & & 6 \\
\hline
\end{tabular}

\subsection{Design of the Study}

The present research was both qualitative and quantitative. A descriptive survey was designed to explore the extent to which written peer feedback was implemented, students' attitudes towards its application at the Faculty of Foreign Languages at a university in Ho Chi Minh City. The descriptive survey with the means of questionnaire and interviews was conducted to investigate whether written peer feedback was applied and, if any, the extent to which written peer feedback activities were carried out, and English-majored students' attitudes towards the practice of written peer feedback.

Questionnaires were instruments that provided respondents with a series of questions or statements and their responses to the questions would be carried out by either writing their answers or selecting choices among existing answers (Brown, 2011). Questionnaires were economical, fast, practical, and useful for a large-scale survey. They could help the researcher elicit longitudinal information from participants in a short period (Mackey \& Gass, 2005). They were regarded as an efficient instrument for gathering data. In this research, one set of questionnaires was designed to gather data from students.

Interviews were employed to gather quality data for the research to work out the extent to which written peer feedback was applied in the Faculty of Foreign Languages at a university in Ho Chi Minh City. Interviews were the most effective method to enlist respondents' cooperation in a survey (Fraenkel \& Wallen, 1996). A core advantage of the interview was the adaptability which allowed the interviewer to follow up ideas, probes responses. Responses in the interviews could be developed and clarified to search for in-depth information on the topics (Bell, 1993). In the descriptive survey, one set of semi-structured interview questionnaire was designed to take data from teachers.

\subsection{The Procedure of the Study}

The descriptive survey of the present research was conducted in the second and third semesters of the academic year. During the second semester, the questionnaire was delivered to the students in WRT1 and WRT3 classes. Also, teacher interviews were held to explore in-depth information for data analysis. To acquire the whole view of peer feedback implementation, the questionnaire was distributed to the students in WRT2 classes in the third semester of the academic year.

As an important instrument in gathering information, the questionnaire was administered to participants in two different periods to collect data from various groups of participants. The 20 -item questionnaire was handed out to the students of WRT1 and WRT3 in the second semester and the students of WRT2 in the third semester of the academic year. Direct administration to different groups of participants was applied so that research could get a high rate of response and had the opportunity to explain the study and answer any questions from the respondents before they complete the questions (Fraenkel \& Wallen, 1996). The copies of the questionnaire were directly delivered to 240 English-majored students selected as the samples of the study in the two final weeks of the second semester of the academic year. All the participants, especially those from Writing-1 classes, were able to have general opinions on what they had experienced during the course. Second, in the third semester of the year, the questionnaire was similarly directly delivered to the 120 participants in Writing- 2 classes. They were 
asked to complete the questionnaire in the two last final weeks of the course. All of the participants were asked to respond to the questionnaire in 15 minutes. Then, the questionnaires were collected. The survey was successfully conducted thanks to the help and cooperation of the teacher in charge of writing classes chosen. The results were then collected and recorded into a datasheet of SPSS version 18 for further analysis to find out the current situation of using peer feedback in the Faculty of Foreign Languages and students' attitudes on its appliance.

Semi-structured interviews were the second research tool to collect data. They were conducted at the end of the second semester of the academic year. Appointments with three teachers: 2 full-time teachers and 1 part-time teacher were made. Each interview approximately lasted for 25 minutes. The participants were asked to answer the questions face to face. At the beginning of the interview, the researcher explained the purposes of the interviews so that they had a clear understanding of what they were doing. All the interviews were recorded and transcribed, which were used for the qualitative analysis of the research.

\section{Findings}

\subsection{The Demographic Data of the Participants}

Concerning the survey participants, eleven classes including 4 Writing-1 (WRT1) classes, 3 Writing-2 classes (WRT2), and 4 Writing-3 (WRT3) classes were cluster-randomly selected out of twenty-two English-majored Writing classes of the Faculty of Foreign Languages at a University in Ho Chi Minh City. The participants from WRT1 and WRT3 were studying in the second semester of the academic year. In the third semester of the academic year, the students in 3 WRT2 classes participated in the study.

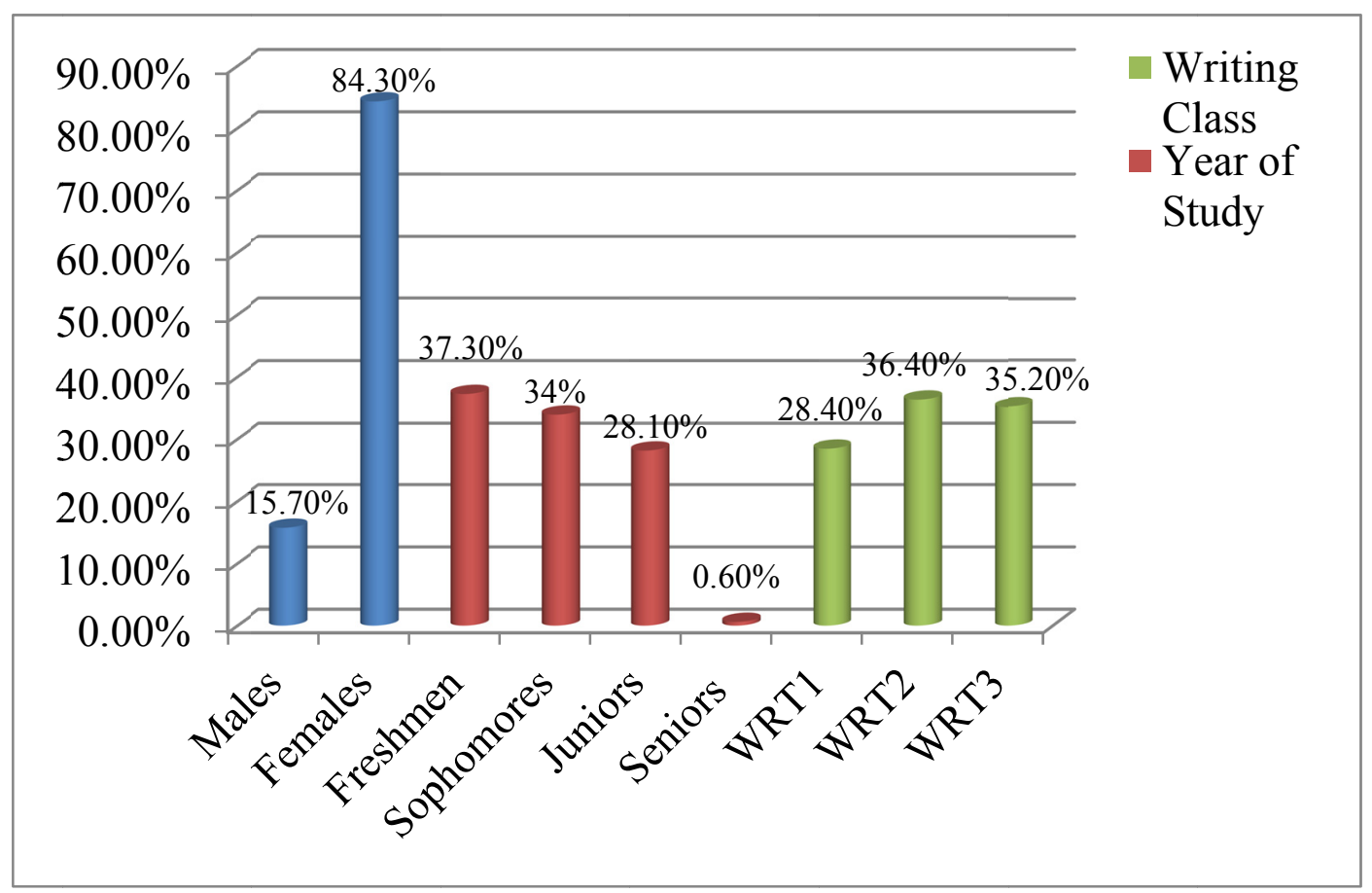

Figure 1. Demographic data of the survey participants

To the questionnaire, the demographics of the students revealed that $15.7 \%$ of them were males and $84.3 \%$ were females. This number is because in language classes the number of females always outweighs the number of males. Regarding years of study, $37.3 \%, 34 \%, 28.1 \%$, and $0.6 \%$ were the figure of freshmen, sophomores, juniors, and seniors respectively. Also, the data disclosed that $28.4 \%$ of them were taking WRT1, $36.4 \%$ were covering WRT2, and $35.2 \%$ were experiencing WRT3. Interestingly, the least number of participants (WRT2) taken from sampling with 3 classes exceeded the number of participants from WRT1 (4 classes) and WRT3 (4 classes). It could be explained that most of the students in WRT2 classes completed and returned the questionnaire but some of the participants from WRT1 and WRT3 classes did not. To the interviews, all of the teachers were females. 


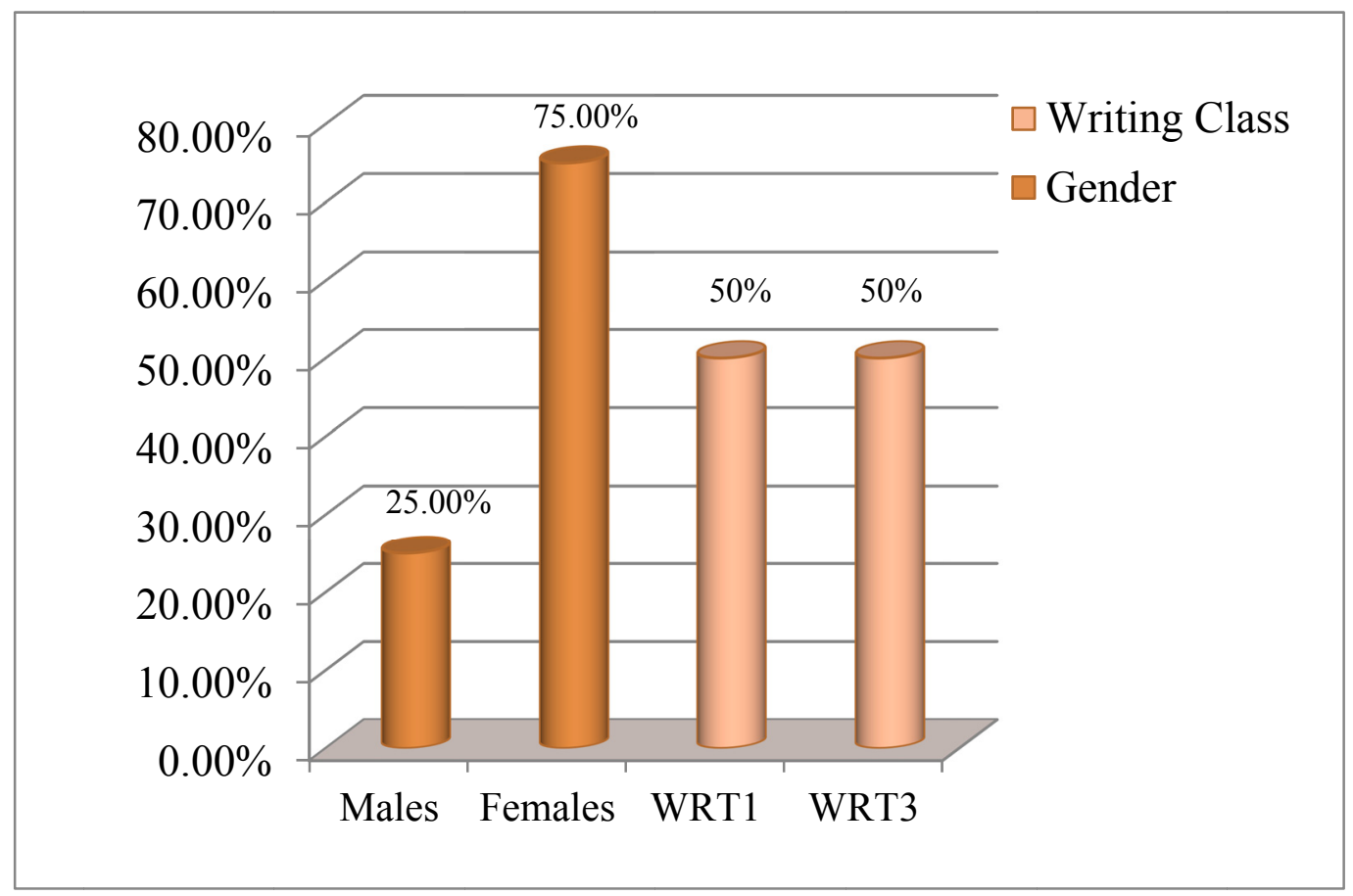

Figure 2. Demographic data of the case study participants

Concerning the case study which was carried out in the second semester of the academic year, 92 students participated in the study. 45 and 47 were the number of participants who came from WRT1 and WRT3 classes respectively. At the end of the course, 20 students with 40 drafts were cluster-randomly selected for data analysis. There were 10 students from the WRT1 class and 10 students from WRT3. The demographic data showed that $75 \%$ (15 students) of the participants were females and 25\% (5 students) of them were males.

\subsection{Research Question 1: To What Extent Is Written Peer Feedback Applied in English Academic Writing Classes in the Faculty of Foreign Languages at HCMC OU?}

Quantitative and qualitative analyses were conducted to answer this research question. Quantitatively, it was examined through questions number 1 to number 7 of the questionnaire, which was designed to explore whether teachers in the Faculty of Foreign Languages at HCMC OU applied written peer feedback in teaching academic writing to English-major students (question 1) and if the training was carried out during the process of feedback (questions 2 to 7). Interviews were the research tool applied to obtain qualitative data. Teacher interviews were conducted to explore in-depth information for the research question on the implementation of written peer feedback.

\subsubsection{Quantitative Analysis}

Concerning the quantitative data, SPSS 18.0 was employed to analyze data. The descriptive statistic was calculated to determine the Number (N), the Mean (M), and the Standard Deviation (SD). The range means for the six-point Likert scale is applied as follows: low level is less than 2.66, the medium level is from 2.67 to 4.33 , and the high level is from 4.34 to 6 (Pham, 2010). The extent to which WPF was applied was displayed in Table 2. 
Table 2. The extent to which WPF was applied

\begin{tabular}{|c|c|c|c|c|}
\hline Item No. & Content & $\mathbf{N}$ & Mean & SD \\
\hline 1 & $\begin{array}{l}\text { Before handing your writing to your teacher, you have the chance to work with your friend to } \\
\text { improve the quality of your writing. }\end{array}$ & 334 & 4.64 & 1.40 \\
\hline 2 & The teacher lets you correct your peer's writing pieces without his/her instructions. & 335 & 4.36 & 1.31 \\
\hline 3 & $\begin{array}{l}\text { The teacher instructs you how to read and written give feedback on your peers' writing } \\
\text { pieces. }\end{array}$ & 337 & 4.12 & 1.53 \\
\hline 4 & $\begin{array}{l}\text { The teacher usually checks your written comments and shows you how to make comments } \\
\text { effectively. }\end{array}$ & 337 & 3.84 & 1.58 \\
\hline 5 & $\begin{array}{l}\text { The teacher provides you with specific guidelines that guide you on how to comment on your } \\
\text { peers' product. }\end{array}$ & 337 & 4.35 & 1.30 \\
\hline 6 & The teacher helps you revise the content and organization of your peers' products. & 336 & 4.30 & 1.26 \\
\hline 7 & $\begin{array}{l}\text { The teacher shows you ways to explain your peers' mistakes and give suggestion when } \\
\text { reading and commenting on their products }\end{array}$ & 337 & 4.25 & 1.36 \\
\hline
\end{tabular}

Table 2 showed the implementation of WPF (written peer feedback) and trained WPF. As indicated in the questionnaire, whether or not there was an implementation of WPF was examined in research question 1. The majority of the respondents agreed that they were provided chances to work with their peers to revise and improve the writing quality before handing into their teacher $(\mathrm{M}=4.64 ; \mathrm{SD}=1.40)$. It meant that peer feedback which was praised for bringing enormous benefits to students' development of writing skills was applied in writing classes in the Faculty of Foreign Languages at HCMC OU.

Medium level of agreement $(\mathrm{M}=4.12 ; \mathrm{SD}=1.53)$ found in question 3 on the instruction given by teachers on ways to read and generate comments showed that trained peer feedback was not sufficiently practiced by all teachers. They did not regularly check students' comments to help them make comments effectively, which was found out in question $4(\mathrm{M}=3.84 ; \mathrm{SD}=1.58)$, but (question 2) let students self-correct their peer's writing drafts $(\mathrm{M}=4.36 ; \mathrm{SD}=1.31)$. An average number of students $(\mathrm{M}=4.25 ; \mathrm{SD}=1.36)$ admitted that teachers showed them ways to explain their peer's mistakes and give suggestions for their peers' improvement (question 7).

Fortunately, students were provided with guidelines on how to comment on their peers' products $(\mathrm{M}=4.35$; $\mathrm{SD}$ $=1.30$ ). The provided guidelines were to avoid students to give vaguely positive comments. Also, they were instructed to revise the content and organization of their peers' product $(\mathrm{M}=4.30 ; \mathrm{SD}=1.26)$, the purpose of which was to help students enrich their writing instead of solo focusing on mechanical mistakes. These results were respectively shown in questions 5 and 6 of the questionnaire.

In sum, the quantitative data from question 1 to number 7 indicated that peer feedback was employed in teaching academic writing classes in the Faculty of Foreign Languages at a university in Ho Chi Minh city though the implementation was not completely achieved. Teachers provided students with guidelines on giving comments on several aspects of writing including content and organization. However, they did not pay enough attention to students' responses to their peers' writing pieces when practicing to better their comments and suggestions.

\subsubsection{Qualitative Analysis}

Qualitative data from the interviews were taken into account in answering the first research question on the implementation of WPF. Face-to-face interviews with 3 teachers of academic English writing were conducted to get in-depth information according to the research question. Their teachers participating in the interviews were coded $\mathrm{T} 1, \mathrm{~T} 2$, and $\mathrm{T} 3$.

Indeed, though the method of teaching/learning writing is not the focus of the current study, both process-oriented and product-oriented writing teaching approaches were employed to supplement each other and bring the utmost benefits to student's development of writing skills. All of the teachers who participated in the present study went on the same teaching process: brainstorming, freewriting, outlining, drafting, and editing. Students were supposed to compose several drafts before coming to the final one which was handed in. In which process, most of them were provided models of the writing genres and guidelines and instructed to work in groups to correct each other's writing products. However, in some cases, the group works in teaching writing were not carried out. According to teacher 1 (T1), only if students had considerable knowledge of writing, they would be designated for doing peer editing; but, if the students' level were low, they would not be assigned to work in a group but individually. T1 claimed that 'depending on students' English competence $[\ldots]$ if their level is low, I will ask them to write independently. Otherwise, I let them work in $\mathrm{n}$ group, making outline and writing essays.' 
Consequently, majority of the teacher participants, although, put peer feedback into practice, to some extent, its implementation was not sufficient. One teacher merely employed 'group-peer' feedback acts as the sample conducted by the teacher. Feedback was practiced with the whole class as a sample in each class meeting which was conducted by the teacher due to the belief that the students' proficiency was too low to practice peer feedback in groups. Therefore, the main source of comments students received was from the teacher in charge.

Because of the students' poor competence, I did not carry out peer feedback as a group activity. For example, with the outline, I simply asked one group to write out their product on the board, encouraged other groups to find out mistakes. Which groups could point out the mistake, they got bonus marks. That was what I did. I knew that if I required them to comment on their group member's products, they would not do.

(Teacher 1)

Although the majority of the teacher ( 2 of them) encouraged students to participate in group work and practice peer feedback, they did not properly employ this activity. First, they provided students with a checklist to work on the process of evaluating their peers' products; however, the problem was that according to teacher 3 (T3) students were required to tick 'yes' or 'no' on the checklist instead of writing out their comments, which helps reviewers develop their writing for clarification.

I gave them a checklist on which they simply ticked 'yes' or 'no' [...] I understood my students, they would vaguely comment some words in general if they were asked to write out their comments. Therefore, the checklist was provided so that they figured out whether there was a thesis statement, including topic and controlling ideas, and topic sentences. [...] They were not required to write out their comments for they would pen silly pieces of stuff, which consumed our time to check, causing a headache.

(Teacher 3)

Second, peer feedback was conducted in-class hours without providing guidelines. Teacher 2 (T2) revealed that after the first draft, students did the peer editing in-class hours. This led students to mainly feedback on the mechanical mistakes instead of content and organization though they were verbally reminded by the teacher.

I merely let them feedback on their peers' products without guidelines. However, I instructed them how to do the editing, what steps they need to follow [...] most of the students correct their peer's mistakes on grammar and vocabulary but not content. As a result, when they submitted their writing, I could see that they had revised their text full of red and black ink; however, the content was kept unchanging.

(Teacher 2)

In sum, the answer to research question 1 on the extent to which WPF was implemented in the Faculty of Foreign Languages at HCMC OU was that WPF was applied at the University but the appliance was not effective due to some reasons. First, trained peer feedback was not carried out on the learning process, which led students not to acknowledge the importance and the role of peer feedback on their language writing development. Second, regarding guidelines on the peer feedback process, in one case, the teacher did not offer students guidelines on what criteria need focusing. As a result, students paid attention to only grammar and vocabulary aspects. In other cases, although guidelines were provided to help students when commenting on their peers' products, they failed to create a chance for students to expose to writing for clarification, suggestion, etc. due to ticking 'yes' or 'no' option. Third, because of the belief that students were not qualified enough to generate comments on their peer's products, peer feedback was merely employed as a sample conducted by the teacher.

\subsection{Research Question 2: What Are English-Majored Students' Attitudes Towards Written Peer Feedback Applied in Academic Writing Classes?}

From the findings in research question 1 that written peer feedback (WPF) was implemented in the Faculty of Foreign Languages at HCMC OU; however, training on WPF was not sufficiently carried out. Research question 2 was to explore the students' attitudes towards WPF currently applied by the teachers. Instruments employed to work out the answer for this research question $\mathrm{n}$ was a questionnaire to students. Quantitative analysis was conducted to analyze the data. Quantitatively, it was examined the questions number 8 to number 20 of the questionnaire. Question 8 was to work out whether the students preferred using WPF on learning English academic writing. Questions 9 to 15 were designed to elicit the students' attitudes towards the uses of WPF. Questions 16 to 20 were for the exploration of the opinions on the effects of WPF on their writing revisions.

SPSS 18.0 was employed to analyze data. The descriptive statistic was calculated to determine the Number $(\mathrm{N})$, the Mean (M), and the Standard Deviation (SD). The range means for the six-point Likert scale is applied as 
follows: low level is less than 2.66, the medium level is from 2.67 to 4.33 , and the high level is from 4.34 to 6 (Pham, 2010).

The questionnaire from the descriptive survey has analyzed the find out students' attitudes towards the practice of peer feedback in terms of its usefulness to their writing quality and its effects on their revisions were displayed in Table 3.

Table 3. Students' attitudes towards the implementation of WPF

\begin{tabular}{|c|c|c|c|c|}
\hline Item No. & Content & $\mathbf{N}$ & Mean & SD \\
\hline \multicolumn{5}{|c|}{ The usefulness of written peer feedback activities for writing quality } \\
\hline 8 & I like my friends in my group to read and comment on my writing. & 336 & 4.95 & 1.10 \\
\hline 9 & $\begin{array}{l}\text { I find it useful to write an essay, revise my drafts, and comment on my peers' writing in } \\
\text { learning English writing. }\end{array}$ & 337 & 4.99 & 1.04 \\
\hline 10 & $\begin{array}{l}\text { Thanks to my peers' comments, I can realize that my writing has many mistakes which I } \\
\text { cannot point out by myself. }\end{array}$ & 336 & 5.14 & 0.95 \\
\hline 11 & $\begin{array}{l}\text { Thanks to my peers' feedback, I understand more about the method of writing an } \\
\text { academic essay. }\end{array}$ & 334 & 4.98 & 2.41 \\
\hline 12 & $\begin{array}{l}\text { Thanks to reading my peers' writing in the commenting process, I learn different writing } \\
\text { styles and ideas from my friend. }\end{array}$ & 335 & 5.02 & 0.92 \\
\hline 13 & $\begin{array}{l}\text { Learning writing via written peer feedback, reading and commenting on my peers' } \\
\text { writing and vice versa, helps me come up with new ideas to revise my writing. }\end{array}$ & 334 & 5.04 & 0.95 \\
\hline 14 & $\begin{array}{l}\text { Written peer feedback is very effective for me since it helps not only me but also my } \\
\text { friends to improve our writing. }\end{array}$ & 336 & 5.02 & 0.91 \\
\hline 15 & $\begin{array}{l}\text { Thanks to written peer feedback, I realize that learning activities are not only based on } \\
\text { the teacher but also my friends so that every member of the class can help each other to } \\
\text { improve our writing quality. }\end{array}$ & 336 & 5.08 & 0.95 \\
\hline 16 & $\begin{array}{l}\text { Sharing my writing for my friends to read and comment makes me pay more attention to } \\
\text { my writing quality. }\end{array}$ & 334 & 4.99 & 0.98 \\
\hline
\end{tabular}

Table 3 indicated that most of the respondents expressed highly favorable and positive attitudes towards the practice of written peer feedback with the mean value ranging from 4.84 to 5.14. Concerning the usefulness of peer feedback, as could be seen from the table, the majority of the students showed their preference in using written peer feedback in learning writing with the mean value varying from 4.95 to 5.14. (9) They enjoyed receiving feedback from their peers $(\mathrm{M}=4.95 ; \mathrm{SD}=1.10)$. (10) They found that it was helpful to write an essay, revise their drafts, and comment on their peers' writing in the learning L2 writing ( $\mathrm{M}=4.99 ; \mathrm{SD}=1.04)$. (11) They strongly agreed that thanks to their peer feedback, they could realize the mistakes that were difficult to be pointed out by themselves $(\mathrm{M}=5.14 ; \mathrm{SD}=0.95)$. (12) Also, they confirmed that thanks to the practice of peer feedback, they understood more about the method of writing an academic essay $(\mathrm{M}=4.98$; $\mathrm{SD}=2.41)$. (13) They asserted that they gained new ideas and learned different writing styles from reading their peers' essays (M $=5.02 ; \mathrm{SD}=0.92)$. (14) Thanks to the commenting process, the student writers could come up with new ideas to revise their writing $(\mathrm{M}=5.04 ; \mathrm{SD}=0.95)$. (15) Besides, they believed that peer feedback helped not only them but also their friends to improve their writing $(\mathrm{M}=5.02$; $\mathrm{SD}=0.91)$; therefore, $(16)$ they highly agreed that their learning could come from two sources - the teacher and friends $(\mathrm{M}=5.08 ; \mathrm{SD}=0.95)$.

Table 4. The effects of written peer feedback on writing revisions

\begin{tabular}{|c|c|c|c|c|}
\hline 17 & I found that my peers' comments are very useful for my writing revision. & 334 & 4.90 & 1.00 \\
\hline 18 & $\begin{array}{l}\text { Thanks to my written peers' comments, I can reorganize the ideas in my writing more } \\
\text { logically. }\end{array}$ & 334 & 4.98 & 0.98 \\
\hline 19 & $\begin{array}{l}\text { After each revision based on my peers' comments, the content of my writing is much more } \\
\text { abundant. }\end{array}$ & 334 & 4.87 & 1.04 \\
\hline 20 & $\begin{array}{l}\text { After each revision based on my peers' comments, my writing greatly improved in terms of } \\
\text { vocabulary, grammar, and spellings. }\end{array}$ & 334 & 4.84 & 1.03 \\
\hline
\end{tabular}

As can be seen from Table 4, the students highly rated the effects of written peer feedback on writing. The range of the means was from 4.84 to 4.99. (17) Most of the students claimed that sharing their writing for their peers to read and comment made them pay more attention to their writing pieces $(\mathrm{M}=4.99 ; \mathrm{SD}=0.99)$. Also, they found 
that their peers' comments (18) were extremely useful for their revision $(\mathrm{M}=4.90 ; \mathrm{SD}=1.00)$, and (19) thanks those comments, they reorganized the ideas in their writing more logically $(\mathrm{M}=4.98 ; \mathrm{SD}=0.98)$. They asserted that after each revision based on their peers' comments, their writing was much improved (20) not only in term of vocabulary, structure, grammar, and spelling $(\mathrm{M}=4.84 ; \mathrm{SD}=1.04)(19)$ but also the content $(\mathrm{M}=4.87 ; \mathrm{SD}=$ $1.04)$.

In short, most of the students expressed their highly positive attitudes towards written peer feedback $(M=4.95)$ in terms of its usefulness for writing quality improvement and its effects on revisions. They believed that it helped not only the writers but also the reviewers improve their writing quality $(\mathrm{M}=5.02)$. Also, they considered it a useful tool in learning writing $(\mathrm{M}=4.99)$ which brought them better revision in both low level $(\mathrm{M}=4.87)$ and high level $(M=4.84)$. Noticeably, the findings from this research question contradicted those based on qualitative data analysis in research question 1 that students were not qualified enough to generate effective comments for peer revision improvement. Therefore, an examination into the quality of peers' written feedback and its effects on the students' revisions was a need.

\subsection{Discussions of the Findings}

With regards to the extent to which peer feedback was implemented, the results of the present study revealed that written peer feedback was applied in English academic writing classes at a University in Ho Chi Minh City. This is consistent with the finding of previous research conducted by Pham (2013). However, trained peer feedback was not sufficiently practiced by all of the teachers. Previous research findings have sought out that without adequate training, students might discomfort with the practice of peer feedback for the lack of trust in their peers' competence, experience anxiety when giving critical feedback, and consider this is time-consuming (Widiati, 2002; Pearce, Mulder, \& Bial, 2009). Therefore, the researcher in an agreement with Pham (2013) suggested that to utilize the advantages of peer feedback, training should be applied.

The teachers provided students with some guidelines and asked students to self-correct their peers' products without regular observation. They, even, did not show students how to explain their peers' mistakes and give suggestions for improvement. Other previous research has proved that, to ensure the effects of written peer feedback, training on peer feedback, in which process students were instructed ways to explain the nature of problems, and give suggestion (Min, 2006; Pham \& Usaha, 2016; Pham et al., 2020; Pham, 2019), should be carried out to empower students in learning and create a collaborative learning environment for writing classes (Hyland, 2000; Tsui \& Ng, 2000; Hyland \& Hyland, 2006).

Semi-structured interviews with teachers revealed that most of the teachers practiced written peer feedback in teaching writing. However, its implementation was not adequately treated. First, they provided students with a checklist to evaluate their peers' products. Students were required to put the tick on the 'yes' or 'no' option. They claimed that without specific guidelines students would provide vague feedback on their peers' writing. Min (2008) argued that in the process of evaluating peers' products, writing their comments would help reviewers develop their writing for clarification.

Second, the teachers verbally instructed students on how to do the editing their peers' products and what steps needed to follow and asked them to practice merely in-class hours. This made students commented on the mechanical mistakes instead of the content and organization. Berg (1999) stated that the peer-editing sheet should be provided to students now that they acknowledged particular writing aspects that needed focusing.

Third, the teachers believed that students were not qualified enough to generate comments on their peers' products; thus, peer feedback was merely employed as a sample conducted by the teacher. In contrast, Graves (1983) and Tangpermpoon (2008) claimed that the writing process is learner-center; thus, teachers should create an involved and motivated environment for writing classes by helping students develop critical thinking and learn not to depend only on teachers' feedback. Supported the notion, Ting and Qian (2010) and Farrah (2012) asserted that peer feedback activities could stimulate self-correction among students and nurture students' independent and critical reading and writing. Also, Min (2008) asserted that trained peer feedback helped students understand that the purpose of giving comments is to assist writers to express their intended ideas comprehensibly; hence, they would provide revision-oriented comments. Moreover, once understanding the purpose, the students were excited about giving comments and willing to spend time and effort on negotiating ideas and giving specific suggestions. Morra and Romano (2008) added that trained peer feedback helped prevent tension and fears; hence, it facilitated student involvement.

Most of the teachers in the Faculty of Foreign Languages at this university applied written peer feedback on teaching academic writing - encouraging students to work in groups and comments on their peers' writing products. However, the practice was not sufficiently adopted. (1) Trained peer feedback was not carried out 
during the learning process. (2) Because of the belief that students were not qualified enough to generate comments on their peer product, (a) in some cases, simple guidelines with 'yes'/"no' options which failed to encourage students to write for clarification and suggestion were delivered to the students, (b) peer feedback was merely employed as a sample conducted by the teacher. The researcher recommended trained written peer feedback to teachers in the Faculty of Foreign Languages at HCMC OU to utilize the practice of peer feedback (Berg, 1990; Widiati, 2002; Min, 2006, 2008; Morra \& Romano, 2008; Pham, 2010). If students were properly trained for peer feedback, they could generate effective comments, which, in turn, eased teachers' burden on large classes. Hence, learner-center in process writing approach was successfully practiced. The recommendation would be enforced with the findings from research questions 2, 3, and 4.

Relating to the students' attitudes towards the implementation, the research findings revealed that the students reported positive attitudes towards every aspect of peer feedback with the mean value ranging from 4.84 to 5.14 . The study found that the students especially preferred having their writing product read and commented on by their peers. The findings lent support to Hirose's (2008), Morra and Romano's (2008), and Pham and Nguyen (2020) that students highly valued the significance of peer feedback. For example, Morra and Romano found that $90 \%$ of their student participants considered the experience of giving feedback was beneficial.

Although written peer feedback was not adequately implemented as revealed in research question 1, students expressed their preference for its practice. The finding, slightly different from Fujieda's (2007), could be, at first, doubted; yet, should come as no surprise since it was fully supported by process writing and collaborative learning approach. These approaches emphasize on learner-centered. Lounis (2010) and Pham and Nguyen (2020) stated that feedback was provided to nurture students' confidence as a writer; however, with time limitation teacher feedback was often for the small groups and class as a whole, peer feedback was the best choice for students writing development. Besides, Nunan (1992) claimed that collaborative learning environments offered learners an effective context for understanding and that they could feel free in expressing ideas in small groups.

Regarding the usefulness of written peer feedback, the results of the present study verified a claim that peer feedback was useful as a source for revisions. First, as mentioned by Jacobs et al. (1998) and Pham and Nguyen (2020), learners were not, sometimes, aware of their writing mistakes because of their carelessness or knowledge gap; this research also revealed that thanks to peer feedback, students could realize the mistakes that were difficult to notice by themselves. Second, peer feedback helped improve not only the writer's writing but also the reviewers' since they learned different writing styles when reading their peers' writing. The finding seemed to bolster Fujieda's (2007), Pham and Nguyen (2020), Pham (2014), and Min's (2008), that as a reviewer, peer feedback provided them with opportunities to read and learn from other texts, raised their awareness of their writing mistakes; as a writer, it helped them receive comments on what they had missed. Yet, it was inventible compared to the drawbacks of L2 peer feedback posted by Fallows and Chandramohan (2001) that students disliked commenting on their peers' work since they believed that it was the teacher's responsibility.

Third, regarding learning sources, students strongly confirmed that they could learn from both their teacher and their peers. The finding was supported by Chaudron's (1984) that neither teacher nor peer feedback was superior to each other. Yet, the research evidence was in opposition to what Widiati (2003) stated that students doubted the value of peer feedback and likely to look upon their teacher's response because they lack trust in the competence of the reviewers.

Concerning the effects of peer feedback on writing quality, the students highly evaluated the effectiveness of written peer feedback for their writing quality. Admittedly, the findings were not new. They compatible with Jacobs et al. (1989), Qian and Ting (2010), and Farrah (2012) that peer feedback significantly yielded a positive impact on revisions. First, confirmed by related literature (Zhu, 2001) on the benefits of peer feedback, the findings of the present research showed that sharing their writing with peers made them take more care of the writing. Second, they revealed that students believed peer feedback helped students reorganize the ideas in their writing more logically, enhanced the writing quality in terms of vocabulary, structure, grammar, vocabulary, and content. The findings bolstered Widiati's (2003) that students found that their peers' comments helped them not only enrich the content but also improve the organization and the language of their writing.

In short, the findings of the present research revealed that the students highly expressed their favorable attitudes towards the practice of written peer feedback. It was found that the students highly rated its practice since (1) they believed that it was useful for the writing quality; and, it helped the students not only as a writer but also a reviewer, (2) and that the effects of peer feedback on their writing revision were positive - their writing performance was enhanced in every aspect such as vocabulary, grammar, structure, spelling, organization, and 
content. Noticeably, the findings from this research and those from research question 1 seemed to be conflictive, which led to a need for a case study to examine the quality of the students' feedback and its effects on writing revisions.

\section{Conclusion}

This present study explored the implementation of written peer feedback in teaching English writing at a University in Ho Chi Minh City. First, following the trend of the world language teaching and learning towards promoting a learner-centered and collaborative learning environment, written peer feedback was carried out in most of the academic writing classes in the Faculty of Foreign Languages; however, the implementation was not sufficiently. The teacher did create chances for students to work in groups and comment on peers' products; yet, they assigned peer correction work to students without careful instructions or training. This was due to their belief that (1) the student would generate general and vague comments, (2) they were not qualified enough to make comments on their peer writing. The researcher recommended trained written peer feedback to the teachers in the Faculty of Foreign Languages to make the best use of the activity as confirmed by previous researchers (Min, 2006; Min, 2008; Pham, 2019; Pham \& Nguyen, 2020) that trained peer feedback helped students improve their writing quality, and helped novice students generate effective comments on their peer's product.

Second, the present study disclosed the students' positive attitudes towards the practice of written peer feedback through their confirmation of the usefulness of peers' comments and the effects of peers' feedback on their writing outcomes. The students' considered peer feedback a useful source for revisions since thanks to the feedback, they realized the mistakes that were difficult to notice by themselves. Peer feedback brought enormous benefits to both writers and reviewers; hence, they admitted that they could learn from not only their teacher but also their peers. Besides, they claimed that peer feedback helped them reorganize the ideas in their writing, and enhance their writing in terms of vocabulary, structure, grammar, and content. The contradict findings between research questions 1 and 2 led the researcher to carry out a case study in an attempt to work out the quality of trained peer feedback and its impacts on the students' revisions.

\section{References}

Bell, J. (1993). Doing your research project: a guide for first-time researchers in education and social science (2nd ed.). Great Britain: Open University Press.

Berg, E. C. (1999). The effects of trained peer response on ESL students' revision types and writing quality. Journal of Second Language Writing, 8(3), 215-241. https://doi.org/10.1016/S1060-3743(99)80115-5

Brown, J. D. (2001). Using surveys in language programs. United Kingdom: Cambridge University Press.

Bui, Y. N. (2000). Towards teaching writing effectively: An Error Analysis of Elementary Learners' Performance in Writing. Unpublished master thesis.

Caulk, N. (1994). Comparing teacher and student responses to written work. Tesol Quarterly, 28(1), 181-188. https://doi.org/10.2307/3587209

Chaudron, C. (1984). The effects of feedback on students' composition revisions. RELC Journal, 15(2), 1-14. https://doi.org/10.1177/003368828401500201

Cheng, W., \& Warren, M. (1997). Having second thoughts: Student perceptions before and after a peer assessment exercise. Studies in Higher Education, 22(2), 233-239. https://doi.org/10.1080/03075079712331381064

David, J., \& Liss, R. (2006). Effective academic writing 3 (1st ed.). USA: Oxford University Press.

Ekşi, G. Y. (2012). Peer review versus teacher feedback in process writing: How effective. International Journal of Applied Educational Studies, 13(1), 33-48.

Fallows, S., \& Chandramohan, B. (2001). Multiple approaches to assessment: Reflections on the use of tutor, peer, and self-assessment. Teaching in Higher Education, 6(2), 229-246. https://doi.org/10.1080/13562510120045212

Farrah. M. (2012). The impacts of peer feedback on improving the writing skills among Hebron University students. An - Najah Univ. J. Res. (Humanities), 26(1), 179-210.

Fraenkel, R. J., \& Wallen, E. N. (1996). How to design and evaluate research in education. United States of America: McGraw-Hill.

Fujieda, Y. (2007). Perceptional change toward peer response: How writers incorporated feedback into revisions. Kyoai Gakuen Journal, 7, 139-153. 
Grabe, W., \& Kaplan, B. R. (1996). Theory and practice of writing. New York, NY: Longman.

Graves, D. H. (1983). Writing: Teachers and children at work. Portsmouth, NH: Heinemann.

Hirose, K. (2008). Peer feedback in L2 English writing instruction. In JALT2007 Conference Proceedings. Tokyo: JALT.

Hyland, F. (2000). ESL writers and feedback: Giving more autonomy to students. Language Teaching Research, 4(1), 33-54. https://doi.org/10.1177/136216880000400103

Hyland, K., \& Hyland, F. (2006). Feedback on second language students' writing. Language Teaching, 39(2), 83-101. https://doi.org/10.1017/S0261444806003399

Jacobs, G. M., Curtis, A., Braine, G., \& Huang, S. Y. (1998). Feedback on student writing: Taking the middle path. Journal of Second Language Writing, 7(3), 307-317. https://doi.org/10.1016/S1060-3743(98)90019-4

Le, T. K. D. (2008). On applying process approach in teaching writing skill for grade 10 non-major students at Dong da high school. Retrieved from http://data.ulis.vnu.edu.vn/jspui/handle/123456789/568

Leki, I. (1990). Potential problems with peer responding in ESL writing classes. CATESOL Journal, 3(1), 5-19.

Lounis, M. (2010). Students' response to teachers'feedback on writing the case of third-year L.M.D students of English. Unpublished Master Thesis.

Macarthur, A. C., Graham, S., \& Fitzgerald, J. (2006). Handbook of writing research. New York: Guilford Press.

Mackey, A., \& Gass, M. S. (2005). Second language research: methodology and design. London: Lawrence Erlbaum Associates.

Mangelsdorf, K. (1992). Peer reviews in the ESL composition classroom: What do the students think? ELT Journal, 46(3), 274-284. https://doi.org/10.1093/elt/46.3.274

McGourty, J., Dominick, P., \& Reilly, R. R. (1998, November). Incorporating student peer review and feedback into the assessment process (Vol. 1, pp. 14-18). In FIE'98. 28th Annual Frontiers in Education Conference. Moving from 'teacher-Centered' to 'Learner-Centered' Education. Conference Proceedings (Cat. No. 98CH36214), IEEE.

Min, H. T. (2006). The effects of trained peer review on EFL students' revision types and writing quality. Journal of Second Language Writing, 15(2), 118-141. https://doi.org/10.1016/j.jslw.2006.01.003

Min, H. T. (2008). Reviewer stances and writer perceptions in EFL peer-review training. English for Specific Purposes, 27(3), 285-305. https://doi.org/10.1016/j.esp.2008.02.002

Morra, A. M., \& Romano, M. E. (2008). University students' reactions to guided peer feedback of EAP compositions. Journal of College Literacy and Learning, 35, 19-31.

Nguyen, P. T. T. (2012). Peer feedback on second language writing through blogs: The case of a Vietnamese EFL classroom. International Journal of Computer-Assisted Language Learning and Teaching, 2(1), 13-23. https://doi.org/10.4018/ijcallt.2012010102

Nguyen, T. N. (2008). An investigation into students' peer-written feedback in paragraphs writing skills among Intermediate students at Hanoi University of Industry. Unpublished BA. Thesis.

Nguyen, T. T. H. (2010). The application of peer feedback in writing teaching to the 2nd-year students at the faculty of English language teacher education - university of language and international studies -Viet Nam National University, Hanoi. Unpublished MA. Thesis.

Nunan, D. (1992). Collaborative language learning and teaching. Australia: Cambridge University Press.

Pearce, J., Mulder, R., \& Baik, C. (2009). Involving students in peer review: case studies and practical strategies for university teaching. Retrieved August 12, 2014, from http://www.cshe.unimelb.edu.au/

Pham, P. V. H. (2010). Blog-based peer response for 12 writing revision. Doctoral dissertation, School of English, Institute of Social Technology Suranaree University of Technology.

Pham, V. P. H. (2013). Các hoat động dạy và học môn Viết tại Khoa Ngoại ngữ Đại học Mổ Tp. HCM. Tạp Chi Khoa họ truờng Đại hoc Mở TP.HCM, 3(31), 96-115.

Pham, V. P. H., Huyen L. H., \& Nguyen, M. T. (2020) The incorporation of quality peer feedback into writing revision. Asian Journal of Applied Linguistics (Scopus-Q3), 7(1), pp 45-59. Retrieved from https://caes.hku.hk/ajal/index.php/ajal/article/view/732 
Pham, V. P. H. (2019). The Effects of Lecturer's Model e-comments on Graduate Students' Peer e-comments and Writing Revision. Computer Assisted Language Learning. https://doi.org/10.1080/09588221.2019.1609521

Pham, V. P. H., Luong, T. K. P., Tran, T. T. O., \& Nguyen, Q. G. (2020). Should Peer E-Comments Replace Traditional Peer Comments? International Journal of Instruction, 13(1), 295-314. https://doi.org/10.29333/iji.2020.13120a

Pham, V. P. H., \& Nguyen, N. H. V. (2020). Blogging for Collaborative Learning in the Writing Classroom. International Journal of Cyber Behavior, Psychology and Learning, 10(3), 1-11. https://doi.org/10.4018/IJCBPL.2020070101

Pham, V. P. H., \& Pham, N. T. D. (2015). Common Errors in Writing Journals of the English-Major Students at HCMC Open University. Journal of Science (HCMC Open University), 2(14), 52-61.

Pham, V. P. H., \& Usaha, S. (2011). The effectiveness of the blog-based peer response for L2 writing. Journal of Science (Ho Chi Minh City Open University), 3(3), 27-44.

Pham, V. P. H., \& Usaha, S. (2016). Blog-based peer response for L2 writing revision. Computer Assisted Language Learning, 29(4), 724-748. https://doi.org/10.1080/09588221.2015.1026355

Rollinson, P. (2005). Using peer feedback in the ESL writing class. ELT Journal, 59(1), 23-30. https://doi.org/10.1093/elt/cci003

Savage, A., \& Mayer, P. (2005). Effective academic writing 2 (1st ed.). USA: Oxford University Press.

Savage, A., \& Shafiel, M. (2007). Effective academic writing 1 (1st ed.). USA: Oxford University Press.

Tangpermpoon, T. (2008). Integrated approaches to improve students writing skills for English major students. ABAC Journal, 28(2), 1-9.

Thuy, N. H. H. (2009). Teaching EFL writing in Vietnam: Problems and solutions-a discussion from the outlook of applied linguistics. VNU Journal of Foreign Studies, 25(1), 61-66.

Ting, M. E. I., \& Qian, Y. (2010). A Case Study of Peer Feedback in a Chinese EFL Writing Classroom. Chinese Journal of Applied Linguistics, 33(4), 87-98.

Topping, K. (1998). Peer assessment between students in colleges and universities. Review of Educational Research, 68(3), 249-276. https://doi.org/10.3102/00346543068003249

Tran, L. (2001). Using pair work and group work in teaching writing. Teacher's Edition, 5, 22-28.

Tran, L. T. (2007). Learners' motivation and identity in the Vietnamese EFL writing classroom. English Teaching: Practice and Critique, 6(1), 151-163.

Tsui, A. B., \& Ng, M. (2000). Do secondary L2 writers benefit from peer comments? Journal of Second Language Writing, 9(2), 147-170. https://doi.org/10.1016/S1060-3743(00)00022-9

Widiati, U. (2003). Trained Peer Response to Develop EFL Students' Positive Attitudes toward Peer Response. TEFLIN Journal, 14(1), 123-139.

Zhu, W. (2001). Interaction and feedback in mixed peer response groups. Journal of Second Language Writing, 10(4), 251-276. https://doi.org/10.1016/S1060-3743(01)00043-1

\section{Copyrights}

Copyright for this article is retained by the author, with first publication rights granted to the journal.

This is an open-access article distributed under the terms and conditions of the Creative Commons Attribution license (http://creativecommons.org/licenses/by/4.0/). 